\title{
Parallel corpora and contrastive linguistics: Where to look for pitfalls in the translation of information structure
}

\author{
Libuše Dušková \\ Charles University, Prague (Czech Republic)
}

\begin{abstract}
This paper deals with some of the problems encountered in English-Czech contrastive studies of information structure based on parallel texts. It largely focuses on those arising from the different hierarchy of the respective word order principles, the primary one being grammatical function in English, and information structure / functional sentence perspective (FSP) in Czech. Three aspects are considered: linear ordering of clause elements, FSP structure, and the basic distribution of communicative dynamism. Owing to the character and complexity of the FSP factors, word order, context, semantics and intonation, and the lack of distinctive realization forms of the carriers of the FSP functions, the study is based on manual excerpts from passages of digitalized running text of three English novels and their Czech translations drawn from the InterCorp. The results show that most problems arise in the case of different linear ordering as it may indicate either an identical or a different FSP structure.
\end{abstract}

Keywords: functional sentence perspective, linear ordering, basic distribution of communicative dynamism, translation counterpart, English/Czech

\section{Introduction}

The present paper addresses some of the problems encountered in English-Czech contrastive studies of information structure based on parallel texts. Most of these problems result from the nature of this methodology itself: nevertheless, it is irreplaceable insofar as it is the only methodology that provides expression of the same content worded in different languages.

The main problems involved in this approach to language comparison have been outlined in a previous paper (Dušková, 2017), where this method was addressed from two aspects: a historical overview of English-Czech contrastive studies based on original texts and their translations since their beginnings in the fifties of the last century; and the variability of translation counterparts, discussed on the basis of two translations of the same novel. ${ }^{1}$ The historical survey has shown three recurrent topics: the condensed structure of the English sentence vs. Czech subordinate finite clauses, English verbo-nominal predicates vs. Czech verbal ones, and arrangements of the information structure in English and Czech

\footnotetext{
${ }^{1}$ A passage from Kingsley Amis's Lucky Jim, translated by Jiří Mucha in 1954 and Kateřina Hilská in 2011. 
within the theoretical framework of functional sentence perspective (FSP). The topic of the present article was suggested by the last point on the ground of its being the least elaborated and the most complex one.

As regards the pitfalls of this methodology, one of them, viz. the influence of the source language on the translation, was pointed out at the very beginning by Vachek (1955) and Hladký (1961), who studied the Czech counterparts of the English condensed sentence structure.

Another problem appeared in the choice of relevant translation counterparts in connection with their non-uniqueness, reflected in actual or potential variability. Contrastive studies of points from the level of clauses and sentences appear to yield relevant results where the comparison is based on such counterparts that reflect all semantic elements of the clause or sentence of the source language and whose adequacy is shown by the recurrence of the same translation patterns in all the samples making up the research material. ${ }^{2}$ On the other hand, instances of free translation of clause and sentence structure do not as a rule contribute to displaying systemic relations. They may of course be of interest from other viewpoints, especially where their use indicates absence of parallel devices in the target language. The problem here is drawing a borderline between "close" and "free" translation. In this paper "free" translation counterparts have been excluded from the analysis. An example of free translation is given in (1).

(1) A strange asymmetry, stopped him being girlishly handsome. (Galbraith)

Tváŕ měl zvláštně asymetrickou, což ho zachraňovalo před vyloženě dívčím půvabem. (Šenkyř́k)

[Face he-had strangely asymmetric, which him saved from patently girlish charm.] ${ }^{3}$

A similar problem was encountered in the shifts observed in the rendition of the information structure. Translation counterparts deviating from the information structure of their source language originals, apart from possible mistakes or slips on the part of the translator, may be due to changes in the semantic structure. More frequently, however, it is the information structure alone that displays minor or greater shifts. It is this point that the present paper attempts to clarify in the following sections. As will be shown, a shift in the information structure need not reflect a translation failure, but may be due to a lack of means in the target language serving the same function, or it may be a case of indeterminacy / potentiality that offers more interpretations even in the source language.

\section{The theoretical framework of FSP}

Information structure is here conceived within the theoretical framework of functional sentence perspective (FSP), developed by Firbas (1992), and further elaborated by his Brno co-workers. ${ }^{4}$ Functional sentence perspective is defined as the distribution of degrees of communicative dynamism (CD) over the elements of the sentence. Degrees of CD are defined "as the relative extent to which a linguistic element contributes towards the further development of the communication" (Firbas, 1992: 8). If the elements of the sentence are arranged according to a gradual rise in their degrees of $\mathrm{CD}$, the sentence displays the basic

\footnotetext{
${ }^{2}$ Cf. Johansson's concept of "translation paradigm" (2007: 23).

${ }^{3}$ Literal translation or exact formal rendition, where needed, is added in square brackets.

${ }^{4}$ The FSP theory goes back to Vilém Mathesius (1975), the founder of English-Czech contrastive studies. The original Czech text of A Functional Analysis of Present Day English dates from the 1920s and 1930s.
} 
distribution of communicative dynamism (Firbas, 1992: 10). In terms of the principal FSP functions the sentence displays the ordering theme - transition - rheme. The transition is prototypically realized by the verb, the theme and the rheme are defined as the elements carrying, respectively, the lowest and highest degrees of CD (Firbas, 1992: 72-73). The definition of the rheme coincides with the concept of end focus (Quirk et al., 1985: 1356-57; Leech, 1983: 22, 64-65) but the conception of the theme differs. In the so-called British approach, the theme is defined by its initial position (Quirk et al., 1985: 1361-62; Halliday, 1994). On the other hand, the FSP structure is based on degrees of communicative dynamism irrespective of the position of the carriers of the FSP functions which, in the clausal FSP field, are represented by the respective clause elements. Their FSP functions are determined on the basis of four factors: context in/dependence, semantics, linear modification (word order) and intonation (prosody) in speech (Firbas, 1992: 10-11). An element can be disengaged from context dependence through the factors of selection, contrast, identification, purposeful repetition and the summarizing effect (Firbas, 1995: 22).

Correspondence in the FSP structure between the original and the translation counterpart is important as even an adequately rendered semantic structure of a clause, if perspectived differently, fails to convey the communicated meaning of the original.

So far, contrastive studies of the FSP structure have been mostly concerned with English and Czech with English as the source language. For treatment in the opposite direction see, e.g., Malá (2017). As regards other language pairs, e.g. Mojžíšová (2009) compared the cleft sentence in English and Norwegian, Dubec (2013) used Czech translation as a supporting device for determining the FSP structure of the Norwegian existential construction, and Aurová (2016) compared the FSP structure in Spanish and Czech. On the whole, however, there exist relatively few contrastive FSP studies of language pairs other than English-Czech few and far between.

In this paper the point under investigation is the FSP clausal field as such, i.e. the higher fields in complex sentences and the lower fields of phrases (except where acting as counterparts of clauses) are left aside. The main aim of the comparison is to find out whether or not the original clause and its counterpart express the same FSP structure, i.e. if the semantic elements constituting the theme and the rheme in the original correspond to the semantic elements that constitute, respectively, the theme and the rheme in the translation. The third main FSP function, transition, owing to its specific nature, has been left for further study.

Of the four factors determining the FSP functions, context dependence / independence (which largely coincides with given vs. new) and semantics are not language specific, and neither is the position of the intonation centre as it normally falls on the rheme. Unlike these factors, the fourth, word order (linear ordering, linear modification), is governed by different rules in English and in Czech. While in analytic English it primarily performs the grammatical function, in inflectional Czech it serves to indicate the information structure. In neutral, non-affective clauses the rheme as a rule stands at the end, irrespective of the syntactic function of its carrier. Accordingly, Czech linear ordering largely coincides with the basic distribution of communicative dynamism, or at least with the principle of end focus (taking into account the ordering in the transitional and thematic sections where it varies and often deviates from a gradual rise in CD). The principle of end focus is ascribed general validity and also operates in English, even though it may be, and often is, counteracted by the grammatical word order principle. ${ }^{5}$ Consequently, all clauses and their translation counterparts are examined with respect to the following configurations: instances displaying

\footnotetext{
${ }^{5}$ For this point, see Chapter 10, Basic distribution of communicative dynamism vs. nonlinear indication of functional sentence perspective, in Dušková (2015: 82-92).
} 
(a) the same linear ordering of clause elements and the same FSP structure, (b) different linear ordering and identical FSP structure, (c) different linear ordering and different FSP structure, and (d) the same linear ordering and different FSP structure.

\section{Material and method}

The material was drawn from three English novels and their translations into Czech (see Sources: J. P. Barnes's Nothing to be Frightened of, Douglas Adams's The Long Dark TeaTime of the Soul), Robert Galbraith's The Silkworm). Successive clauses of running text were excerpted from the opening pages of each source until their number reached 100, i.e. 300 clauses in total. The excerption was confined to the narrative parts, direct speech was excluded. Owing to the character and complexity of the FSP factors, word order, context in/dependence, semantics and intonation, and the lack of distinctive realization forms of the carriers of the FSP functions, the excerption had to be done manually, with the help of the digitalized versions of the texts available in InterCorp. Both finite and non-finite clauses were included on the ground that they differ only in the expression / non-expression of the subject and the operator, which are here inherently thematic, hence the information structure of the clause as a whole is not affected. Verbless clauses were taken into account only where they had finite or non-finite counterparts in the other language.

Each English clause and its Czech counterpart were considered with respect to agreement / disagreement from three aspects: linear ordering, FSP structure and basic distribution of communicative dynamism, the last being one of the linear arrangements of the FSP structure which coincides with the principle of end focus.

\section{Relations between linear ordering and FSP structure}

4.1 Clauses with corresponding and non-corresponding linear ordering and FSP structure

The primary classification of the material into clauses whose linear ordering of semantic elements and the FSP structure correspond, and clauses in which the two variables disagree is presented in Table 1.

Table 1. Relations between the same linear ordering and (non-)corresponding FSP structure.

\begin{tabular}{llrrr}
\hline & & Number of clauses & $\begin{array}{c}\text { Corresponding } \\
\text { linear ordering and FSP }\end{array}$ & $\begin{array}{c}\text { Non-corresponding } \\
\text { linear ordering and FSP }\end{array}$ \\
\hline Adams & Finite & 73 & 43 & 30 \\
& Non-finite & 26 & 17 & 9 \\
& Verbless & 1 & 1 & - \\
Total & & 100 & 61 & 39 \\
\hline Barnes & Finite & 69 & 50 & 19 \\
& Non-finite & 27 & 22 & 5 \\
& Verbless & 4 & 3 & 1 \\
Total & & 100 & 75 & 25 \\
\hline Galbraith & Finite & 80 & 43 & 37 \\
& Non-finite & 17 & 11 & 6 \\
Total & Verbless & 3 & 3 & - \\
\hline Total & & 100 & 57 & 43 \\
\hline
\end{tabular}


As shown by the figures, correspondence between English and Czech in linear ordering and FSP structure is found in almost two thirds of the examples. The ordering here represents the basic distribution of $\mathrm{CD}$ with the theme at the beginning, the rheme at the end, and the transition in between. Compare the examples listed under (2).

(2) a. Strike fished in his overcoat pocket (Galbraith) Strike zalovil v kapse kabátu (Šenkyřík)

b. The taxi-driver had been bad-tempered (Adams) Taxíkář byl mrzutý (Hollanová)

c. until she married my grandfather, Bert Scoltock (Barnes) než se vdala za mého dědečka, Berta Scoltocka (Fantys)

Agreement between English and Czech in linear ordering and the FSP structure representing the basic distribution of $\mathrm{CD}$ is mostly found in clauses with one post-verbal clause element which is context-independent, as illustrated in (2): adverbial, subject complement, and object, respectively. The examples listed under (2) differ only in the realization forms of the clause elements. In (2) a. the form of the Czech adverbial differs in having the modifier construed as a genitive 'pocket of coat', (2) b. has different morphemic structures of the corresponding lexical items and different tenses (explicit reference to an anterior past action in English by the past perfect vs. the past tense in Czech), while (2) c. displays differences in the morhemic structure and government of the verb: the English verb takes direct object, whereas the Czech verb is reflexive (cf. the reflexive particle se) and takes a prepositional object governed by the preposition za (marry / provdat se za).

Similar instances with more than one post-verbal element are rarer since here not only does context independence play a role, but, in the case of adverbials, also their semantics. Temporal and locative adverbials with scene-setting semantics, whose basic position is at the end in English, are components of the thematic section. The examples given under (3) illustrate post-verbal adverbials that further specify the verbal action.

(3) a. that it arrived at your front door in a hot cardboard box (Adams) že přichází k vašim dveřím v horké kartónové krabici (Hollanová)

b. as he walked down the slope towards Smithfield Market (Galbraith) Když se pustil ze svahu ke Smithfieldské tržnici (Šenkyř́ík)

The Czech counterparts in (3) a. and b. differ in the expression of the subject, cf. the personal pronouns in English against personal endings of the verbs in Czech $\underline{i t}$ arrived / pricház- $\underline{i}, \underline{h e}$ walked / pustil- $\underline{Q}$ se, further in the reflexive form of the verb in (3) b. walked / pustil se (which corresponds to set out rather than to walk), and absence of tense shift in Czech: past tense in English it arrived vs. present tense in Czech prichází.

The overall percentage $64.3 \%$ of correspondence in linear ordering and FSP structure is in good agreement with the results of previous studies $(62.2 \%$, cf. Note 5, Dušková, 2015: 184 ) and confirms the general validity of the end-focus principle, subject to the restrictions imposed by the grammatical system of English. In the three samples, however, the percentages of these clauses differ: while the Barnes sample considerably (almost by 10\%) exceeds the average, in the Galbraith sample their representation is lower (57\%), with Adams's percentage close to the average. These differences partly reflect the authorial styles and partly the translators' adherence to the original. While the prevailing simple clause 
structure in Barnes's narrative offers straightforward counterparts, Galbraith's complex sentence structure makes greater demands on the translator's choices.

\subsection{Clauses with identical FSP structure and different syntactic structure}

The figures in the column Corresponding linear ordering and FSP in Table 1 include two groups of examples: the first comprises instances that display agreement between English and Czech not only in the linear ordering of semantic elements and the FSP structure, but also in the syntactic structure. This group was exemplified in Section 2.1 by examples (2) and (3). The second group displays agreement in the first two of the three variables, but the syntactic structure is different. The syntactic shifts between English and Czech can again be differentiated according to whether they concern the finite, non-finite or verbless form of the clause or the syntactic functions of the clause elements. Predictably, in the case of English finite clauses, no Czech non-finite counterparts were found. However, there were a few instances of correspondence between an English finite and a Czech verbless clause (a prepositional phrase), cf. (4).

(4) He ate ... (Galbraith)

Při jídle [during meal] (Šenkyř́ík)

In contrast, also predictably, the correspondence between English non-finite and Czech finite clauses was frequent (Adams 10 out of 26, Barnes 13 instance out of 27, Galbraith 15 out of 17), cf. (5a), (5b), and (5c). Finite counterparts in Czech were also found in the marginal group of English verbless clauses, cf. (5d).

(5) a. (Norway was not at all a good place) for her to go. (Adams)

(Norsko rozhodně není vhodným místem), kam by měla jet [where she should go]. (Hollanová)

b. (He had decided) to specialize in the British Empire. (Barnes)

(Rozhodl se,) že se omezí [that he would specialize] na Britské impérium. (Fantys)

c. beneath a stone griffin standing sentinel on the corner of the market building. (Galbraith)

Pod kamenným gryfem, který držel stráž [which stood sentinel] na rohu budovy tržnice, (Šenkyř́ík)

d. (listening to the story) of her infatuation, (Galbraith)

(poslouchal př́iběh o tom), jak se bláznivě zamilovala [how herself foolishly shefell-in-love], (Šenkyř́ík)

The shifts in the syntactic functions of clause elements largely display patterning that has been observed in previous studies in connection with English passive - Czech active and English verbo-nominal - Czech verbal predication (Dušková, 2015: 30-45, 57-83, 107-137), cf. (6) and (7), respectively.

(6) a. most of her life had been spent at a constant distance from it. (Adams) většinu života $a_{\text {accusative }}$ strávila $_{\text {active }}$ ve stálém odloučení od něj. 
b. her Worker was now supplemented by China Reconstructs, (Barnes)

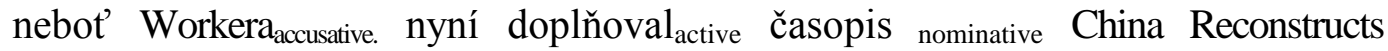
(Fantys)

(7) a. they ... were of that generation (Barnes) patřili [belonged to] ke generaci (Fantys)

b. so Strike made a detour down a side alley (Galbraith) a tak Strike odbočil [turned] do postranní uličky (Šenkyřík)

Another recurrent pattern was found in English initial subjects corresponding to a Czech initial adverbial or object (in an active clause), cf. (8):

(8) a. But my grandmother's life had contained another enormous change (Barnes)

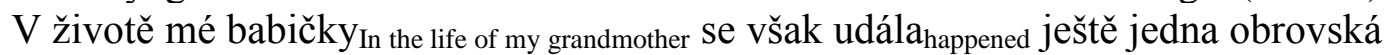
změna $_{\text {nominative. }}$ (Fantys)

b. All the way out of London to Heathrow she had suffered from doubt. (Adams) Celou cestu $\mathrm{z}$ Londýna na Heathrow ji $\mathrm{i}_{\text {her accusative }}$ sužovaly $_{\text {worried }}$ pochybnosti ${ }_{\text {doubt }}$ nominative (Hollanová)

Other syntactic shifts were documented by single instances, e.g. English copular qualifying predication - Czech existential sentence (which corresponds to the existential construction in English), cf. (9)

(9) and if it was remotely possible, (Adams)

a pokud je byt' i jen vzdálená možnost [and if there is only a remote possibility] (Hollanová)

The recurrent patterns illustrated by (6), (7) and (8) have been noted and described in previous studies (Brůhová and Malá, 2017; Malá, 2014; Dušková, 2012; 2015: 30-45), the first and the third showing, in connection with the basic distribution of $\mathrm{CD}$, systemic differences between English and Czech, due to the different function of word order: while in Czech the basic distribution of CD can be achieved by word order alone, final placement of the rheme in English may result from the subject construction of a thematic post-verbal element, which in the case of the object often involves the use of the passive.

Different syntactic structure was also found in the configurations of noncorrespondence between linear ordering and FSP structure, but here the two variables do not appear to be systemically related.

4.3 Clauses with non-corresponding English and Czech linear ordering and FSP structure

The different types of non-correspondence between English and Czech in the linear ordering of clause elements and FSP structure are summarized in Table 2. 
Table 2. Relations between non-corresponding linear ordering and FSP structure.

\begin{tabular}{|c|c|c|c|c|c|}
\hline & & $\begin{array}{l}\text { Different ordering } \\
\text { - same FSP }\end{array}$ & $\begin{array}{l}\text { Different ordering } \\
\text { - different FSP }\end{array}$ & $\begin{array}{l}\text { Same ordering } \\
\text { - different FSP }\end{array}$ & Total \\
\hline \multirow[t]{3}{*}{ Adams } & $\begin{array}{l}\text { Finite } \\
\text { clauses }\end{array}$ & 25 & 4 & 1 & 30 \\
\hline & $\begin{array}{l}\text { Non-finite } \\
\text { clauses }\end{array}$ & 6 & 3 & - & 9 \\
\hline & $\begin{array}{l}\text { Verbless } \\
\text { clauses }\end{array}$ & - & - & - & - \\
\hline Total & & 31 & 7 & 1 & 39 \\
\hline \multirow[t]{3}{*}{ Barnes } & $\begin{array}{l}\text { Finite } \\
\text { clauses }\end{array}$ & 15 & 3 & 1 & 19 \\
\hline & $\begin{array}{l}\text { Non-finite } \\
\text { clauses }\end{array}$ & 4 & 1 & - & 5 \\
\hline & $\begin{array}{l}\text { Verbless } \\
\text { clauses }\end{array}$ & 1 & - & - & 1 \\
\hline Total & & 20 & 4 & 1 & 25 \\
\hline \multirow[t]{3}{*}{ Galbraith } & $\begin{array}{l}\text { Finite } \\
\text { clauses }\end{array}$ & 24 & 12 & 1 & 37 \\
\hline & $\begin{array}{l}\text { Non-finite } \\
\text { clauses }\end{array}$ & 3 & 2 & 1 & 6 \\
\hline & $\begin{array}{l}\text { Verbless } \\
\text { clauses }\end{array}$ & - & - & - & - \\
\hline Total & & 27 & 14 & 2 & 43 \\
\hline Total & & 78 & 25 & 4 & 107 \\
\hline$\%$ & & 72.9 & 23.4 & 3.7 & 100 \\
\hline
\end{tabular}

\subsubsection{The largest group of non-correspondence}

The largest group of non-correspondence between English and Czech comprises clauses that display different ordering and the same FSP structure. This group accounts for almost threequarters of all instances displaying non-correspondence between the linear ordering of clause elements and FSP structure. Although this might appear to be a major pitfall, most instances of this type show the non-correspondence to be a consequence of the grammatical function of English word order. The same FSP structure with a different linear ordering in English and Czech is mostly found in clauses displaying context-dependent post-verbal clause elements, adverbials and objects, realized by anaphoric proforms, which clearly indicate their appurtenance to the thematic section. In the Czech counterparts they appear in the preverbal position, cf. (10). The differences in the linear ordering between English and Czech are indicated by graphic marking: the corresponding clause elements are marked in the same way, by italics and underlining, respectively.

(10) a. the Italian owner placed tea in front of him in a tall white mug, (Galbraith) italský majitel restaurace už před něho postavil čaj ve vysokém bílém hrnku, (Šenkyř́k)

b. the pizza problem, which drove her crazy. (Adams) až na známý problém s pizzou, který ji doháněl k šílenství. (Hollanová)

c. $\quad$ and that he would call her from there. (Adams) a že jí [her] odtamtud [from there] zavolá. (Hollanová)

Example (11) shows a context-dependent object realized by a noun. The anaphoric character of the object is here indicated by the determiner (in underlined italics). 
(11) My brother did not compete for such offerings, (Barnes) Bratr se mnou o tyto lákavé nabídky nesoupeřil.

Another type of non-corresponding linear ordering and identical FSP structure is found in English presentation sentences with the rhematic subject in the pre-verbal or initial position (Firbas, 2010; Adam, 2013) as in (12a). Where the English sentence also contains a final scene-setting adverbial, the Czech counterpart displays a complete reversal of the positions of the theme and the rheme, which stand in their regular positions, the theme at the beginning and the rheme at the end, cf. (12b).

(12) a. In the late 1950s, the Sino-Soviet Schism took place, (Barnes) Koncem padesátých let došlo k čínsko-sovětské roztržce (Fantys)

b. a stern stone face, ancient and bearded, stared back at him from over the doorway. (Galbraith) z prostoru nad vstupem opětovala jeho pohled strohá kamenná tváŕ, starověká a vousatá. (Šenkyř́ík)

Less recurrent types of different ordering and similar FSP structure can be illustrated by adverbial modification of the verb, cf. (13).

and sank, with a grunt of satisfaction, onto the hard wood and steel chair. (Galbraith)

a se spokojeným zafuněním usedl na dřevěnou židli s ocelovým kováním. (Šenkyř́k)

However, since the adverbial may occur post-verbally and pre-verbally in both languages, the FSP aspect of these instances calls for more material-based treatment taking into account the relationship between the placement of the adverbial, its semantics where it is contextindependent, and its realization form.

Non-corresponding linear ordering indicating the same FSP structure was also found in the Czech finite counterparts of English non-finite and verbless clauses, cf. (14a) and (14b), respectively.

(14) a. (they were ... of that generation) advised by dentists to ... (Barnes) (patřili ke generaci,) jejímž př́slušníkům zubaři radili, aby ... (Fantys)

b. $\quad$ An embarrassed grunt later (Barnes)

Následovalo rozpačité zabručení (Fantys)

\subsubsection{The second group of non-correspondence}

The second group of clauses with different ordering of clause elements and different FSP structure is represented by less than a quarter of all instances of non-correspondence between linear ordering and FSP structure. Yet it is this group that raises most questions. The most prominent shift is found where the translation counterpart differs from the original in the rheme. However, these instances are often liable to potentially dual interpretation in which 
even the prosodic factor does not offer a conclusive answer. More or less clear-cut instances of different assignment of the rhematic function are illustrated in (15).

(15) a. when the top was down (Barnes)

když se sundala střecha (Fantys)

b. I welcomed this mysterious decision with blunt self-interest, (Barnes)

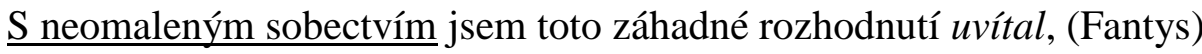

c. not to think about him at all (Adams)

vůbec na něj nemyslet (Hollanová)

d. who ordered tea with an air of defiance, (Galbraith)

který si s mírným odporem objednal čaj (Šenkyřík)

e. (In her savage desire for retribution against a man who ...) she would damage herself and her prospects beyond repair (Galbraith)

(V zuřivé touze pomstít se muži, který ...) by dokázala nenávratně zničit sama sebe i své dalši životni vyhlídky. (Šenkyř́k)

In (15a) the top / strecha is context-dependent as it occurs in a passage describing the car, where the novel element is the change of the position of the top, expressed by the predicative part of the clause. Moreover, in English its realization form clearly assigns the intonation centre to the last element, which corresponds to the Czech verb. The same FSP structure could be expressed by imitating the English verbo-nominal structure, viz. když byla střecha dole, but this is clearly a dispreferred rendition of the given content when compared with the verbal form. The verb here appears to be too 'weak' to carry the FSP function of rheme on its own. The deviation from the FSP structure of the original thus appears to be due to the character of the target language rather than to a slip of the translator.

In (15b) the reason for the shift in the rheme can hardly be sought in the character of the target language insofar as the final position of the Czech adverbial is equally possible. The novel elements in this clause are the verb and the manner adjunct, both nominal elements being context-dependent. While in the original the function of rheme is assigned to the adverbial, in Czech it is the verb that constitutes the rheme. Although the FSP structure of adverbial modification of the verb in Czech is a point for further study (cf. the comment on (13) in Section 4.3.1), in this case the realization forms of the two elements - univerbal verb welcomed / uvital, expanded form of the adverbial with blunt self-interest / s neomalenym sobectvim dispose the adverbial to operate as the rheme. It is to be noted, however, that the initial placement of the adverbial in Czech may suggest a different semantic role, viz. that of the subject adjunct, qualification of the subject in the course of verbal action.

In (15c) two semantic features compete for the function of rheme: the negative polarity of the verb phrase and the maximum degree intensifier of the verbal meaning. The linear ordering and the position of the intonation centre in the English clause indicate the intensifier as the rheme, while in Czech it is the negated verb.

In (15d) the only new element is the manner adjunct, the act of ordering tea being fully derivable from the situational context: the action takes place in a café at the time of breakfast while the companion of the actor making the order is eating his breakfast and drinking tea.

Example (15e) illustrates a shift in the rhematic section, specifically the assignment of the function of the rheme proper. In the English clause the components of the rhematic section, the object and the adverbial, are ordered, without regard to the weightiness of their realization forms, according to their degrees of CD: the coordinated object is partly contextdependent, its first conjoin being a reflexive pronoun and the second conjoin through the 
possessive determiner, while the final adverbial, even though less weighty in form, is an entirely new element. In the Czech counterpart, it is the weightiness of the realization forms of the two elements that determines the ordering within the rheme $\left(\mathrm{Rh}_{1}, \mathrm{R}_{2} \ldots\right.$, the last constituting the rheme proper).

Example (16) shows another factor that may contribute to a different FSP structure of a clause, viz. a change in its position within a higher textual unit, in this case a complex sentence. Moreover, the Czech complex sentence corresponds only to the first two clauses of an English multiple sentence that contains altogether four clauses.

(16) The slight unevenness in his gait became more pronounced (as he walked down the slope towards Smithfield Market,) (Galbraith)

(Když se pustil dolů ze svahu ke Smithfieldské tržnici), zvýraznila se mírná nepravidelnost jeho chůze. (Šenkyř́ík)

The subject of the English clause is presented as context-dependent, the actor's gait having been described as tramping in the preceding context. If the clause remained in its original position, the ordering of the elements might be preserved, but being placed after the subordinate clause, the final element appears to need a more weighty realization form than the verb. This case thus may be regarded as a result of the combined effect of a different placement in a higher unit and the realization forms of the elements whose FSP functions have been interchanged.

A different FSP structure due to a different linear ordering was also found among nonfinite clauses, cf. (17). The factor of the change is again to be sought in the relatively light realization form of the rheme.

(17) from being rickety-gnashered to fully porcelained in one leap (Barnes) - jediný skok od vyviklaných zubů k čistě porcelánovému stavu, (Fantys)

The examples adduced in this section have been classed as more or less clear-cut, while in the case of the less clear-cut there is some ground for potentiality, "which occurs when the interplay of FSP factors permit [sic] of more than one interpretation" (Firbas, 1992: 108). An instance of this kind is represented by (18).

(18) Two men in fleeces and waterproofs had just vacated a table. (Galbraith) Od jednoho stolku právě vstali dva muži ve fleecových vestách a nepromokavých bundách. (Šenkyřík)

In (18) all nominal elements are situationally given: the scene is a café at the time of breakfast; what is situationally underivable is the kind of clothing and the quantifier. These elements are components of the realization form of the subject, which makes it weightier and disposes it to operate as the rheme. On the other hand, the final position and the immediately relevant situational context suggest the object for this FSP function: for the new arrival on the scene, the most important point is a vacant table, cf. the immediately preceding sentence: Exhausted and hungry, he turned at last, with the pleasure that only a man who has pushed himself past his physical limits can ever experience, into the fat-laden atmosphere of frying eggs and bacon. Seen in the light of both perspectives, the FSP structure appears indeterminate. 


\subsubsection{The last group of non-correspondence}

The last group of non-correspondence between the linear ordering and FSP structure, identical ordering of elements in the source and the target language expressing different FSP structures, appears to be marginal as it is represented only by four examples. The examples are adduced under (19).

(19) a. (I have no idea) how strong her religious faith had been. (Barnes) (Nemám vůbec představu o tom,) jak silná její víra bývala. (Fantys)

b. (He had just started on his sausages) when Dominic Culpepper arrived. (Galbraith)

Když Dominic Culpepper dorazil, (Strike se zrovna pouštěl do párků). (Šenkyř́ík)

c. (It was almost pathetically easy) to wind up the ex-public schoolboy (Galbraith)

Vytočit někdejšího žáka soukromé školy (bylo až dojemně snadné.) (Šenkyř́ík)

d. as eventually they had crawled past it. (Adams) a když konečně projeli kolem místa neštěstí (Hollanová)

In (19a) the rheme in the English clause is the subject complement ${ }^{6}$ (whose initial position is due to the obligatory fronting of the wh-element) on the ground of its context-independence; it is the only novel element of the clause as the subject is context-dependent not only through the possessive determiner but also owing to its actual occurrence in the immediately preceding context. The corresponding Czech counterpart would have the predicative adjective at the end: jak byla její víra silná. The actual Czech counterpart assigns this function to the final element of the English clause, the verb, as is usual in Czech, and since it carries the intonation centre, its neutral form byla is replaced by the longer iterative form byvala. The most likely source of the FSP shift is here the influence of the original whose linear ordering the Czech counterpart imitates.

In (19b) the interpretation of the FSP structure depends on whether or not the subject is context-dependent. If context-independent, the clause would be a presentation sentence with the Czech counterpart $k d y z \check{z}$ dorazil Dominic Culpepper, i.e. the subject would be placed at the end. Culpepper is mentioned in the preceding context, but there are five intervening paragraphs between this mention and the occurrence in (19b). According to Firbas (1992: 2331) and Svoboda (1981: 88-89), the retrievability span is generally limited to seven intervening clauses. Five paragraphs greatly exceed this limit, which supports the contextindependent interpretation. Nevertheless, characters in novels are given elements throughout the whole texts, which often applies even to the opening passages, as may be the case here, with the FSP structure assigned to potentiality. Dual interpretation of instances of this kind was actually attested by an example in Dušková (2017: 210), which is here reproduced (for the two translations, see Note 1):

\footnotetext{
${ }^{6}$ Subject complements with rhematic function have been found in more than $90 \%$ of their occurrences (Uhlířová, 1974); their rare occurrence in the theme is due to their largely prevalent context-independence.
} 
(19) b.' Welch, Dixon noticed, had rejoined the group (Amis)

Nyní, jak si Dixon všiml, se k nim opět připojil Welch, (Mucha)

Dixon si povšiml, že se k nim Welch vrátil (Hilská)

Here the actor of the action has not been mentioned in a stretch of text covering a page and a half. In these instances, however, a factor in the $\mathrm{S}-\mathrm{V}$ order may also be the influence of the source language.

In (19c) the only novel element in the non-finite clause is the verb, the object referring to one of the interlocutors whose public-school education is a known fact. However, since the order of the clauses has been reversed, a weightier realization form of the object appeared to be a more suitable candidate for the rheme. A corresponding, fully acceptable Czech counterpart of the whole complex sentence constituting (19c) would be Bylo až dojemně snadné někdejšího žáka soukromé školy vytočit, in which the elements are ordered in the same way as in English, with the exception of the reversed position of the infinitive and its object.

The last example (19d) is a clear instance of misrepresentation of the information structure, resulting from neglect of the anaphoric character of the adverbial, univocally indicated by its realization form. A notable consequence is the use of a non-pronominal realization form kolem mista neštěstí 'past the place of the accident'.

Both in this Section and in Section 4.3.2 recurrent sources of the shifts in the FSP structure appear to be a potentially dual interpretation of the FSP structure in the original and preference of a differing structure because it offers a smoother rendition of the content than a possible corresponding structure, which may even be excluded altogether owing to systemic differences between the two languages.

\section{Conclusion}

The preceding discussion attempted to show the intricacies of the semantic and information structure displayed by the translation counterparts at the level of finite, non-finite, and marginally also verbless clauses. Three aspects were considered, linear ordering of the clause elements, FSP structure, and within the latter the basic distribution of communicative dynamism, each contributing to the complexity involved in determining an adequate translation counterpart. Both the same and a different linear ordering in the source and the target language may indicate either a corresponding or a different FSP structure. Of the four configurations under discussion, same linear ordering - same FSP structure, different linear ordering - same FSP structure, different linear ordering - different FSP structure, and same linear ordering - different FSP structure, the least problematic seems to be the same ordering - the same FSP structure since identical ordering rarely constitutes a different FSP structure. According to the frequency of occurrence, it is the other two configurations that present more problems: different ordering in English clauses and their Czech translation counterparts largely indicates the same FSP structure, but also fairly often a different FSP structure. The complexity of the interpretation here results from the interplay of the FSP factors and the different function of word order in Czech and in English. Instances where the original clauses and their translation counterparts differ raise the question whether there are any factors contributing to the shift or whether the shift is to be ascribed to a slip of the translator. Recurrent shift-supporting factors have been found in the realization forms of the clause elements whose FSP function is changed and in the position of a clause within a higher textual unit. As regards instances of dual interpretation of the FSP structure in the original, 
neither interpretation represents an FSP shift, the structure being indeterminate as such. In general, more extensive material and further research may reveal other factors. A question to be asked in particular is whether a different interpretation is not due to a lack of means in the target language for the expression of the FSP structure in the original. While the foregoing English-Czech comparison of the FSP structure does not provide much evidence in this respect, an approach from Czech to English, considering the FSP function of the free Czech word order, is likely to provide more ground for ascertaining systemic differences. In both directions, however, the extent of the research material needs to be enlarged if more insight into the questions raised here is to be gained. How to achieve this is a pitfall of the present state of research.

\section{References}

Adam, M. 2013. Presentation Sentences (Syntax, Semantics and FSP). Brno: Masaryk University, Faculty of Education Work 162.

Aurová, M. 2016. El orden de palabras y el dinamismo comunicativo: una contribución al estudio contrastivo del español y checo. Hermenéus, Revista de Traducción e Interpretación18: 27-58.

Brůhová, G. and Malá, M. 2017. On English Locative Subjects. Acta Universitatis Carolinae, Philologica 2017(1) (Prague Studies in English): 19-38.

Daneš, F. (ed.). 1974. Papers on Functional SentencePerspective. Prague: Academia.

Dubec, P. 2013. Syntactic and FSP Aspects of the Existential Construction in Norwegian. Doctor's Dissertation, Charles University.

Dušková, L. 2012. Vilém Mathesius and contrastive studies, and beyond. In M. Malá and D. Šaldová (eds), 21-48.

Dušková, L. 2015. From Syntax to Text: the Janus Face of Functional Sentence Perspective. Prague: Karolinum Press.

Dušková, L. 2017. Kontrastivní lingvistika a paralelní korpusy. Časopis pro moderní filologii 99(2): 193-213.

Egan, T. and Dirdal, H. (eds). 2017. Cross-linguistic Correspondences. From Lexis to Genres. Amsterdam: John Benjamins.

Firbas, J. 1992. Functional Sentence Perspective in Written and Spoken Communication. Cambridge: University Press.

Firbas, J. 1995. Retrievability Span in Functional Sentence Perspective. Brno Studies in English 21: $17-45$.

Firbas, J. 2010. Non-thematic Subjects in Contemporary English. In A. Svoboda, J. Chamonikolasová and L. Urbanová (eds), 281-298.

Hladký, J. 1961. Remarks on Complex Condensation Phenomena in Some English and Czech Contexts. Brno Studies in English 3: 105-118.

Halliday, M. A. K. 1994. Introduction to Functional Grammar. London: Arnold.

Johansson, S. 2007. Seeing through Multilingual Corpora: On the Use of Corpora in Contrastive Studies. Amsterdam: John Benjamins.

Leech, G. N. 1983. The Principles of Pragmatics. London and New York: John Benjamins.

Malá, M. 2014. English Copular Verbs. A Contrastive Corpus-supported View. Prague: Charles University, Faculty of Arts.

Malá, M. 2017. Non-prepositional English Correspondences of Czech Prepositional Phrases. In T. Egan and H. Dirdal (eds), 199-217.

Malá, M. and Šaldová, P. (eds). 2012. A Centenary of English Studies at Charles University: from Mathesius to Present-day Linguistics. Prague: Charles University, Faculty of Arts.

Mathesius, V. 1975. A Functional Analysis of Present Day English on a General Linguistic Basis. Prague: Academia.

Mojžíšová, K. 2009. The Cleft Sentence in English and Norwegian. Master's Dissertation, Charles University. 
Quirk, R., Greenbaum, S, Leech, G. and Svartvik, J. 1985. A Comprehensive Grammar of the English Language. London: Longman.

Svoboda, A. 1981. Diatheme. Brno: Masaryk University.

Svoboda, A., Chamonikolasová, J. and Urbanová, L. (eds). 2010. Collected Works of Jan Firbas. Vol. 1. Brno: Masaryk University Press.

Uhlířová, L. 1974. On the Role of Statistics in the Investigation of FSP. In F. Daneš (ed), 208-216.

Vachek, J. 1955. Some Thoughts on the So-called Complex Condensation in Modern English. Sborník praci Filosofické fakulty brněnské univerzity (A 3): 63-77.

\section{Primary sources}

Adams, D. 1990 (1988). The Long Dark Tea-Time of the Soul. London: Macmillan Pocket. Dlouhý, temný čas svačiny duše. 2016. Translation Jana Hollanová. Prague: Nakladatelství Argo.

Barnes, J. P. 2008. Nothing to be Frightened of. New York: Knopf Doubleday. Žádný důvod k obavám. 2009. Translation Petr Fantys. Prague: Odeon.

Galbraith, R. 2014. The Silkworm. London: Sphere, Hedvábník. Translation Ladislav Šenkyř́ík. Prague: Nakladatelství Plus, 2015.

InterCorp: Český národní korpus - InterCorp. Prague: Ústav Českého národního korpusu. http://www.korpus.cz [last accessed 12 May 2017]

Author's address

Libuše Dušková

Department of English Language and ELT Methodology, Faculty of Arts

Charles University

nám. Jana Palacha 2

11638 Praha 1

Czech Republic

libuse.duskova@ff.cuni.cz 
Libuše Dušková 